\author{
Krzysztof Parzych \\ Akademia Pomorska w Slupsku \\ Instytut Geografii i Studiów Regionalnych \\ krzysztof-parzych@wp.pl
}

\title{
WYKORZYSTANIE FUNDUSZY EUROPEJSKICH NA ROZWÓJ ZAGOSPODAROWANIA TURYSTYCZNEGO GMIN NADMORSKICH POBRZEŻA BAŁTYKU
}

\begin{abstract}
Abstrakt: W artykule podjęto zagadnienie wykorzystania środków finansowych z funduszy europejskich na rozwój zagospodarowania turystycznego gmin nadmorskich Pobrzeża Bałtyku w Polsce. Dokonano szczegółowej analizy absorpcji funduszy unijnych ze szczególnym uwzględnieniem tych priorytetów, które związane są z poprawą atrakcyjności turystycznej gmin nadmorskich oraz z rozwojem ich zagospodarowania turystycznego. Analizy dokonano na podstawie danych Ministerstwa Rozwoju Regionalnego dotyczących rozdziału środków finansowych z funduszy europejskich objętych finansowaniem w latach 2007-2013.
\end{abstract}

Słowa kluczowe: turystyka, gminy nadmorskie, fundusze europejskie.

\section{WPROWADZENIE}

Rozwój turystyki w regionach recepcyjnych wymaga nakładów finansowych, co wiąże się z zapewnieniem turystom odpowiednich warunków w zakresie podstawowych potrzeb: noclegowych, gastronomicznych oraz innych szeroko rozumianych usług towarzyszących. Ważną rolą inwestycji związanych z rozwojem turystyki $\mathrm{w}$ regionie jest zapewnienie dostępności komunikacyjnej obszaru recepcyjnego poprzez rozbudowę sieci drogowej, kolejowej oraz elementów punktowych infrastruktury transportowej. Dzięki nim powstaną możliwości przemieszczania się turystów między obszarami emisji i recepcji ruchu turystycznego. Ponadto istotne $z$ punktu widzenia turysty są usługi towarzyszące - związane z rozrywką, rekreacją oraz informacją. Wszystkie te działania wymagają zaangażowania odpowiednich środków finansowych.

Współcześnie inwestycje $\mathrm{w}$ branżach bazy noclegowej oraz gastronomicznej i usług towarzyszących są realizowane $\mathrm{w}$ większości przez inwestorów prywatnych, bądź $w$ ramach inwestycji $w$ formie partnerstwa publiczno-prywatnego (BUTOWSKI 2002). Infrastruktura transportowa jest przede wszystkim zapewniana przez samorządy dysponujące środkami publicznymi. W celu rozwoju turystyki w granicach swoich jednostek terytorialnych samorządy realizują ponadto projekty, które mają służyć poprawie atrakcyjności turystycznej - poprzez rewitalizację dawnych układów historyczno-urbanistycznych, usprawnienie systemu informacji turystycznej, ułatwienia odbioru przez turystów punktowych atrakcji turystycznych, stosowanie odpowiednich oznakowań, tablic informacyjnych. Samorządy lokalne podejmują również inwestycje w formie partnerstwa publiczno-prywatnego, których celem jest kreowanie nowych atrakcji turystycznych, jak np. budowa aquaparków, ścieżek rowerowych, torów do narciarstwa wodnego, kręgielni, kompleksów sportowo-rekreacyjnych. Wszystkie przedsięwzięcia infrastrukturalne zarówno o charakterze prywatnym, jak i realizowane $\mathrm{w}$ ramach partnerstwa publiczno-prywatnego, czy przez same samorządy, wymagają wysokich nakładów finansowych, często przekraczających zasoby finansowe gmin oraz pojedynczych inwestorów prywatnych. Konieczne staje się więc poszukiwanie innych źródeł finansowania podejmowanych inwestycji.

Dla wielu gmin, w tym zwłaszcza gmin, których rozwój społeczno-ekonomiczny jest ściśle związany z turystyką, realizacja takich przedsięwzięć to często konieczność, aby pozyskać nowych turystów oraz konkurować z innymi gminami. 
Wraz z akcesją do struktur Unii Europejskiej Polska uzyskała możliwość ubiegania się o dotacje z Funduszy Strukturalnych UE (tj. EFFR i EFS) oraz Funduszu Spójności.

W niniejszym opracowaniu podjęto zagadnienie wykorzystania środków finansowych pochodzących z funduszy europejskich na poprawę atrakcyjności turystycznej oraz rozwój zagospodarowania turystycznego gmin nadmorskich Pobrzeża Bałtyku. Analizy podjętego problemu badawczego dokonano w oparciu o bazy danych Ministerstwa Rozwoju Regionalnego dotyczące finansowania projektów realizowanych $\mathrm{z}$ udziałem dofinansowania $\mathrm{z}$ funduszy europejskich zawartych w zarejestrowanych Umowach i wnioskach o dofinansowanie.

Gminy nadmorskie ze względu na swoje położenie oraz często brak konkurencyjnych alternatyw rozwijania się są bardzo ściśle związane w swoim rozwoju społeczno-ekonomicznym z usługami turystycznymi (MEYER 2006, SZWICHTENBERG 2006, MIEDZIŃSKI 2011, PARZYCH 2012). Jednocześnie $z$ uwagi na fakt, że dla licznych gmin dochody $z$ turystyki stanowią główny składnik budżetu, a sezon turystyczny na polskim wybrzeżu jest relatywnie krótki, dochody wielu samorządów gmin nadmorskich są stosunkowo niewielkie. Część z nich nie ma możliwości realizacji dużych inwestycji o charakterze infrastrukturalnym w oparciu jedynie o środki własne, wobec czego gminy te zmuszone są do poszukiwania innych, dodatkowych środków finansowych.

Fundusze europejskie od momentu akcesji Polski do Unii Europejskiej były głównym źródłem wspierania rozwoju infrastrukturalnego wielu gmin w Polsce. W szeroko pojętej turystyce były one wykorzystywane najczęściej na ochronę i adaptację walorów turystycznych, zarówno przyrodniczych jak i antropogenicznych, do pełnienia funkcji turystycznej oraz na poprawę atrakcyjności turystycznej obszarów. Wspierano dzięki nim promocję walorów przyrodniczych, ochronę środowiska przyrodniczego, zachowanie dziedzictwa kulturowego oraz rewitalizację dawnych układów historyczno-urbanistycznych. W znacznym stopniu ze środków funduszy europejskich realizowane były również inwestycje w rozwój szeroko rozumianego zagospodarowania turystycznego określonych terenów. Dotyczyło to przede wszystkim poprawy dostępności komunikacyjnej miejscowości recepcyjnych, w mniejszym stopniu infrastruktury noclegowej oraz rozwoju usług towarzyszących turystyce.

Problematyka wykorzystania funduszy europejskich w zakresie inwestycji w rozwój turystyczny regionów czy miejscowości recepcyjnych stała się również $\mathrm{w}$ ostatnich latach przedmiotem badań naukowych i doczekała się licznych opracowań o charakterze ogólnym oraz szczegółowych studiów przypadku (BUTOWSKI 2002, 2005, GWOSDZ, MURZYN KUPISZ 2010,
KOŁODZIEJCZYK 2009, PARZYCH 2012, ŻUBER 1999, STAWICKI 2009).

W okresie finansowania 2007-2013 na inwestycje związane z szeroko rozumianą turystyką przeznaczono ponad 8 mld euro. Sumę zagwarantowaną środków zarezerwowanych w "Programach Operacyjnych" na działania w sektorze turystycznym określono na poziomie 4 mld euro. Pozostałe 4 mld euro zostały zagwarantowane w Programie Operacyjnym „Kapitał Ludzki” oraz w „Programie Rozwoju Obszarów Wiejskich". Podstawowymi źródłami finansowania inwestycji służących rozwojowi turystyki z funduszy europejskich są: "Zintegrowany Program Operacyjny Rozwoju Regionalnego” (priorytet: „Rozwój turystyki i kultury"), EWT IINTERREGIVC (program wspierający inicjatywę Komisji Europejskiej - „Regiony dla zmian ekonomicznych") oraz regionalne programy operacyjne.

\section{METODYKA BADAŃ}

$\mathrm{W}$ analizie przyjętego $\mathrm{w}$ artykule problemu badawczego dokonano przeglądu wykorzystania dofinansowania $z$ funduszy europejskich na inwestycje związane $\mathrm{z}$ turystyką we wszystkich gminach nadmorskich województw zachodniopomorskiego i pomorskiego, ze szczególnym uwzględnieniem dofinansowania na projekty umożliwiające poprawę atrakcyjności oraz zagospodarowanie turystyczne gmin.

Atrakcyjność turystyczną w niniejszym opracowaniu rozumie się jako właściwość obszaru lub miejscowości wynikająca z zespołu cech przyrodniczych lub pozaprzyrodniczych, które wzbudzają zainteresowanie i przyciągają turystów (KUREK 2007).

Przez zagospodarowanie turystyczne uważa się zespół urządzeń turystycznych, stanowiących wyposażenie danego obszaru, ukierunkowanych na zaspokojenie potrzeb turystów (KOWALCZYK 2000).

Z 86 priorytetów „Zintegrowanego Programu Operacyjnego Rozwoju Regionalnego" wybrano sześć, zdaniem autora, najbardziej związanych z rozwojem turystyki. Są to priorytety:

1) „Promowanie walorów przyrodniczych" (nr 55.),

2) „Ochrona i waloryzacja dziedzictwa przyrodniczego" (56.),

3) "Inne wsparcie na rzecz usług turystycznych" (57.),

4) "Ochrona i zachowanie dziedzictwa kulturowego" (58.),

5) "Rozwój infrastruktury kulturalnej” (59.), oraz

6) "Zintegrowane programy na rzecz rewitalizacji obszarów miejskich i wiejskich" (61.).

W celu realizacji przyjętego problemu badawczego dokonano: 
- analizy przestrzennej dofinansowania projektów badawczych realizowanych $\mathrm{w}$ gminach nadmorskich $\mathrm{z}$ udziałem funduszy europejskich;

- oceny przestrzennej udziału środków finansowych wykorzystanych na projekty dotyczące turystyki w kwocie ogółem projektów dofinansowanych z funduszy europejskich,

- obliczeń średniej kwoty dofinansowania z funduszy europejskich przypadającej na jednego mieszkańca w gminach nadmorskich Pobrzeża Bałtyku;

- obliczeń średniej kwoty dofinansowania projektów związanych z poprawą atrakcyjności oraz zagospodarowania turystycznego przypadającej na jednego turystę w gminach nadmorskich;

- oceny wpływu liczby ludności gminy i liczby turystów w poszczególnych gminach na kwoty dofinansowania ogółem oraz dofinansowania projektów związanych z poprawą atrakcyjności turystycznej i rozwojem zagospodarowania turystycznego gminy.

\section{WYNIKI BADAŃ}

Polskie wybrzeże rozciąga się na długości $528 \mathrm{~km}$ od Świnoujścia na zachodzie, po Krynicę Morską na wschodzie. Pod względem administracyjnym obszar ten jest podzielony na 32 gminy. Obok dużych gmin miejskich - takich jak gminy trójmiejskie oraz Kołobrzeg, Świnoujście - na terenie Pobrzeża Bałtyku znajdują się tez niewielkie gminy, których ludność nie przekracza 5000 mieszkańców (np. Rewal, Dziwnów czy Postomino). Dla większości gmin nadmorskich, z wyłączeniem największych, dochody z szeroko rozumianej organizacji i obsługi ruchu turystycznego stanowią bardzo duży, a w niektórych przypadkach dominujący udział $w$ dochodach ogółem (SZWICHTENBERG 2006, MEYER 2006). Ponadto dochody z organizacji i obsługi ruchu turystycznego to również główne źródło utrzymania znacznej części ludności wielu gmin nadmorskich. Są one uzależnione od intensywności ruchu turystycznego oraz skali zagospodarowania turystycznego.

Przeprowadzona analiza finansowania projektów realizowanych na obszarze gmin nadmorskich wskazuje na jego silne zróżnicowanie. Ogółem 32 gminy nadmorskie położone na terenie Pobrzeża Bałtyku zostały objęte dofinansowaniem 15590883993 zł. Z tej kwoty największe środki otrzymała gmina miejska Gdańsk, w której zrealizowano projekty na łączną sumę 5747343727 zl, co stanowiło 36,8\% ogółu dofinansowania, jakim zostały objęte wszystkie gminy nadmorskie Pobrzeża Bałtyku (rys. 1). Wśród pozostałych największe fundusze uzyskały: Świnoujście (w wysokości 3901707056 zł - 24,3\% wszystkich środków $\mathrm{z}$ dofinansowania w gminach nadmorskich), Gdynia - 1883011446 zł (12,0\%) i Sopot - 1171264969 zł (7,5\% ogółu). Najmniejsze kwoty zostały przyznane gminom: Smołdzino - 6398414 zl, Choczewo - 9292964 zl, Sztutowo - 11022645 zł i Stegna - 32004411 zł.

Analogicznie największe kwoty z funduszy europejskich otrzymały gminy: Gdańsk - 30079934615 zl (46,6\% ogółu dofinansowania ze środków europejskich w gminach nadmorskich Pobrzeża Bałtyku), Gdynia - 1026748545 zł (15,6\%), Świnoujście - 646857265 (ok. 10\%) i gmina Sopot - 522663727 zł (prawie 8\% wszystkich funduszy europejskich zaabsorbowanych przez nadmorskie gminy Pobrzeża Bałtyku) - por. rys. 1 .

Ważnym czynnikiem determinującym rozwój społeczno-ekonomiczny obszaru jest potencjał demograficzny. Wśród gmin nadmorskich znajdują się gminy o silnie zróżnicowanym potencjale demograficznym. Obok dużych gmin miejskich, takich jak Gdansk, Gdynia, Sopot, Świnoujście, Kołobrzeg, znajdują się też gminy o znacznie mniejszej liczbie ludności, np. jak Rewal, Postomino, Dziwnów. Większe gminy kumulują znacznie wyższe kwoty dofinansowania. Potwierdzeniem tego jest wysoka wartość współczynnika korelacji Pearsona, obliczona dla kwoty zaabsorbowanych przez poszczególne gminy środków finansowych oraz ich liczby ludności, która wyniosła 0,84 .

Analiza średnich kwot dofinansowania przypadających na jednego mieszkańca gmin nadmorskich Pobrzeża Bałtyku wskazuje, że największą siłą absorpcyjną środków finansowych charakteryzowały się gminy: miejska Darłowo (24 430 zł na jednego mieszkańca), Krynica (18 475 zl), Hel (17 736 zl), Świnoujście (15 580 zł), Sopot (13546 zł), Rewal (13 261 zł) oraz Kosakowo (10 216 zl) (rys. 2). Najniższe średnie kwoty dofinansowania na jednego mieszkańca dotyczyły gmin: Choczewo (823 zl), Darłowo gmina miejska (1084 zl), Będzino (1120 zł) oraz Smołdzino (1360 zł). Z sumy 15590883993 zł dofinansowania ogółem, jakim zostały objęte gminy nadmorskie Pobrzeża Bałty$\mathrm{ku}$, około 8,4\% stanowiły środki finansowe przeznaczone na realizację priorytetów: 55., 57., 58., 59. oraz 61. W niniejszym opracowaniu priorytety te zostały uznane jako te, które są związane z poprawą atrakcyjności turystycznej oraz zagospodarowania turystycznego obszarów. Nie odnotowano finansowania z priorytetu 55. „Promowanie walorów przyrodniczych".

Najwyższe kwoty dofinansowania projektów z priorytetów, które dotyczyły poprawy atrakcyjności turystycznej i rozwoju zagospodarowania turystycznego, zaabsorbowano w gminach Gdańsk - było to 616538593 zł (47,2\% wszystkich środków finansowych przeznaczonych na priorytet związany z popra- 


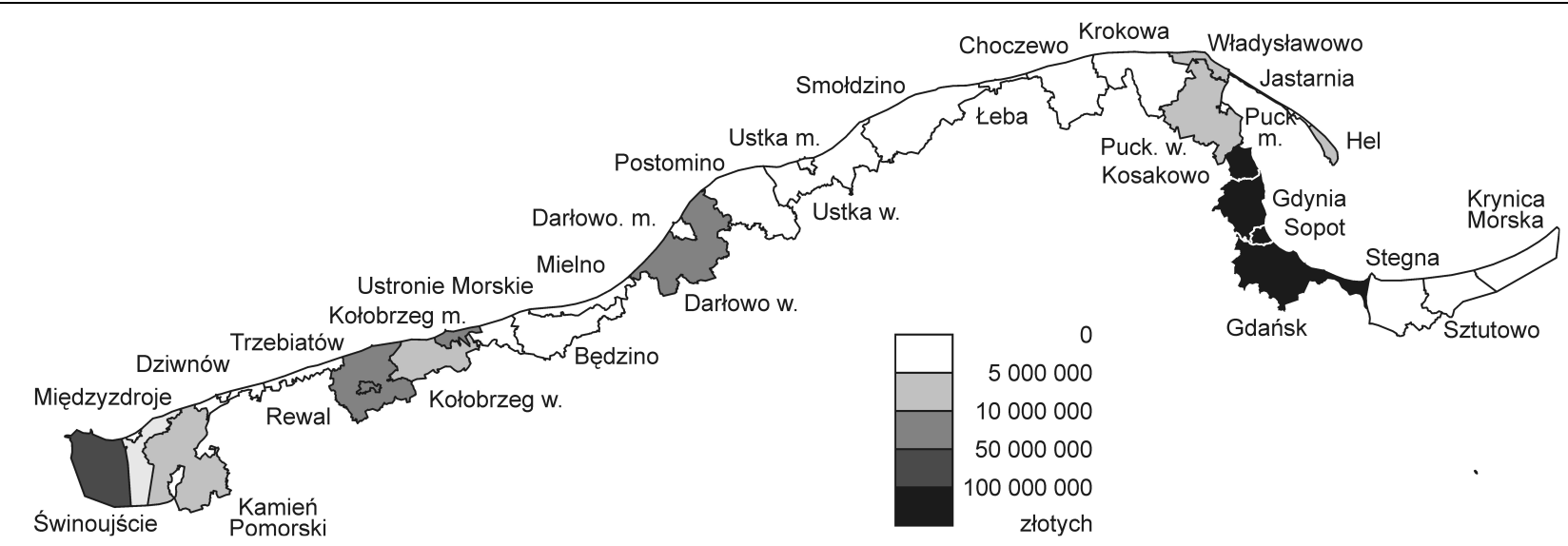

Rys. 1. Wartość europejskiego dofinansowania projektów związanych z turystyką

w gminach nadmorskich Pobrzeża Bałtyku

Źródło danych do rys. 1-6: opracowanie własne na podstawie danych Ministerstwa Rozwoju Regionalnego

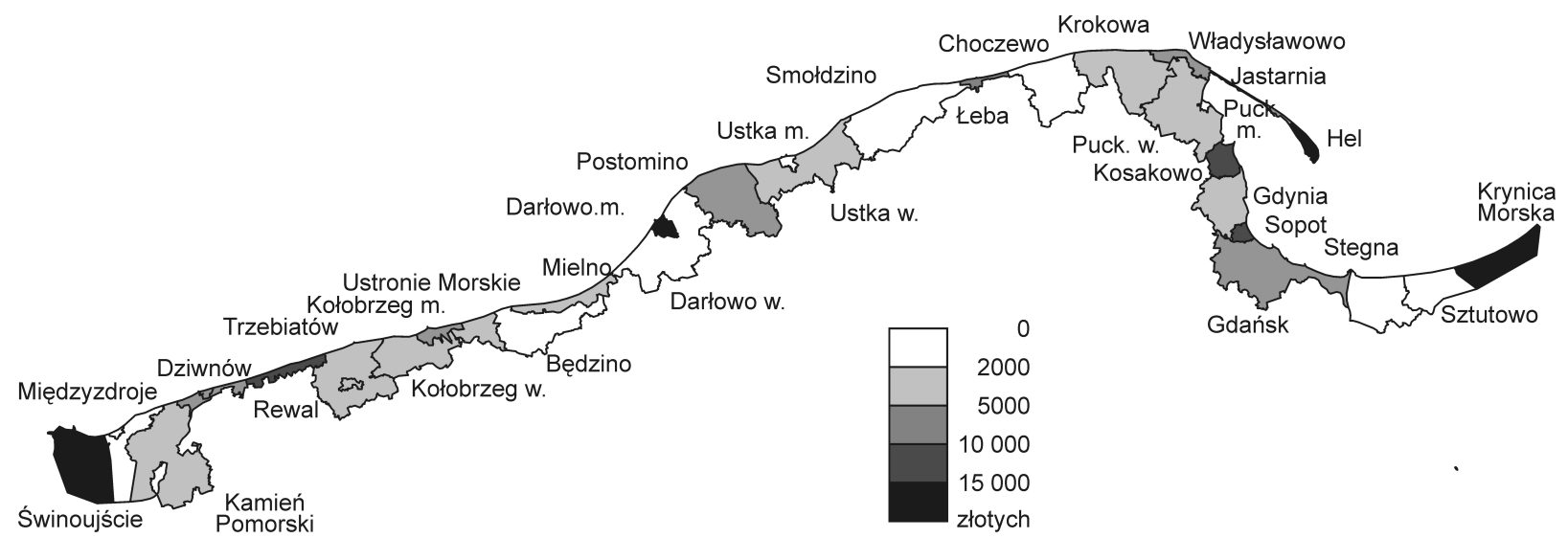

Rys. 2. Średnie dofinansowanie projektów realizowanych z funduszy europejskich na jednego mieszkańca w gminach nadmorskich Pobrzeża Bałtyku

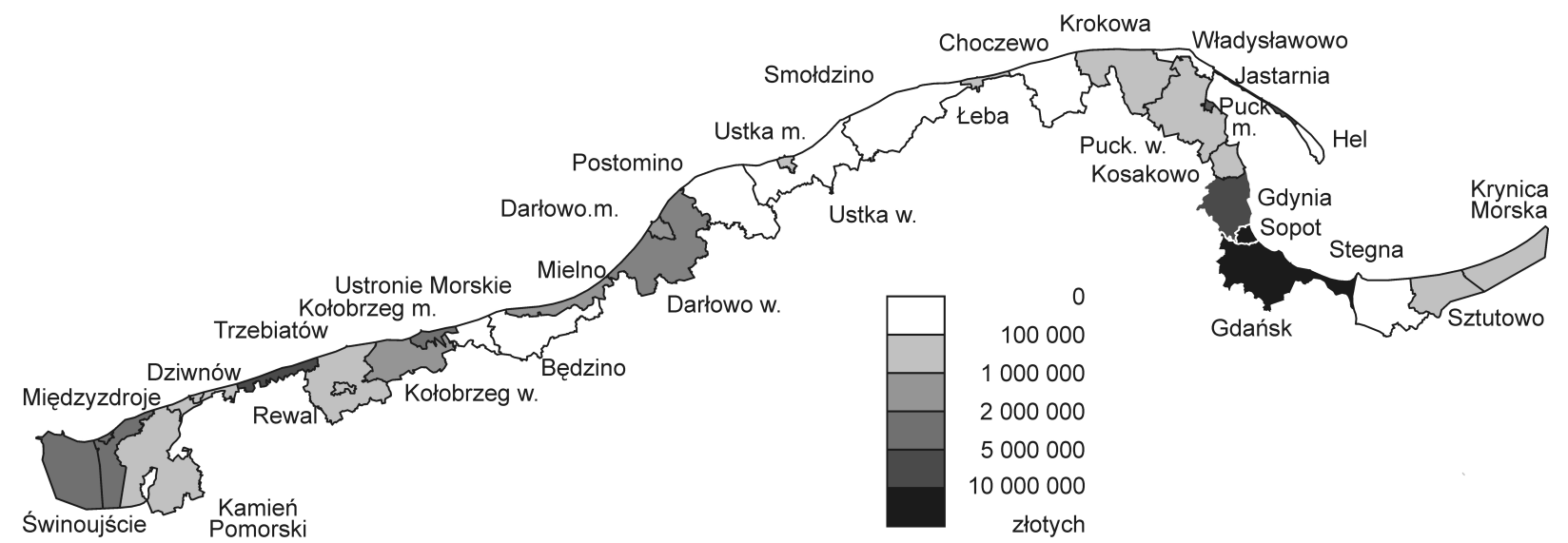

Rys. 3. Wartość środków finansowych z funduszy europejskich wykorzystanych w realizacji projektów związanych z poprawą atrakcyjności i zagospodarowania turystycznego w gminach Pobrzeża Bałtyku

wą atrakcyjności turystycznej oraz rozwojem zagospodarowania turystycznego $\mathrm{w}$ gminach nadmorskich Pobrzeża Bałtyku), Sopot - 292133743 zł (22,3\%), Gdynia - 72129633 zł (5,5\%), Rewal - 57161116 zł (4,3\%), gmina miejska Kołobrzeg - 44242243 zł (3,3\%) oraz w gminach Jastarnia Świnoujście i Międzyzdroje (rys. 3). W sześciu z badanych gmin nadmorskich nie stwierdzono uzyskania funduszy $\mathrm{w}$ ramach dofinansowania wspomnianych priorytetów. Były to gminy: Ustronie Morskie, Będzino, Darłowo, Postomino, Smołdzino oraz Hel. Niskie kwoty dofinansowania zaabsorbowały gminy: Stegna, Władysławowo, Chocze- 


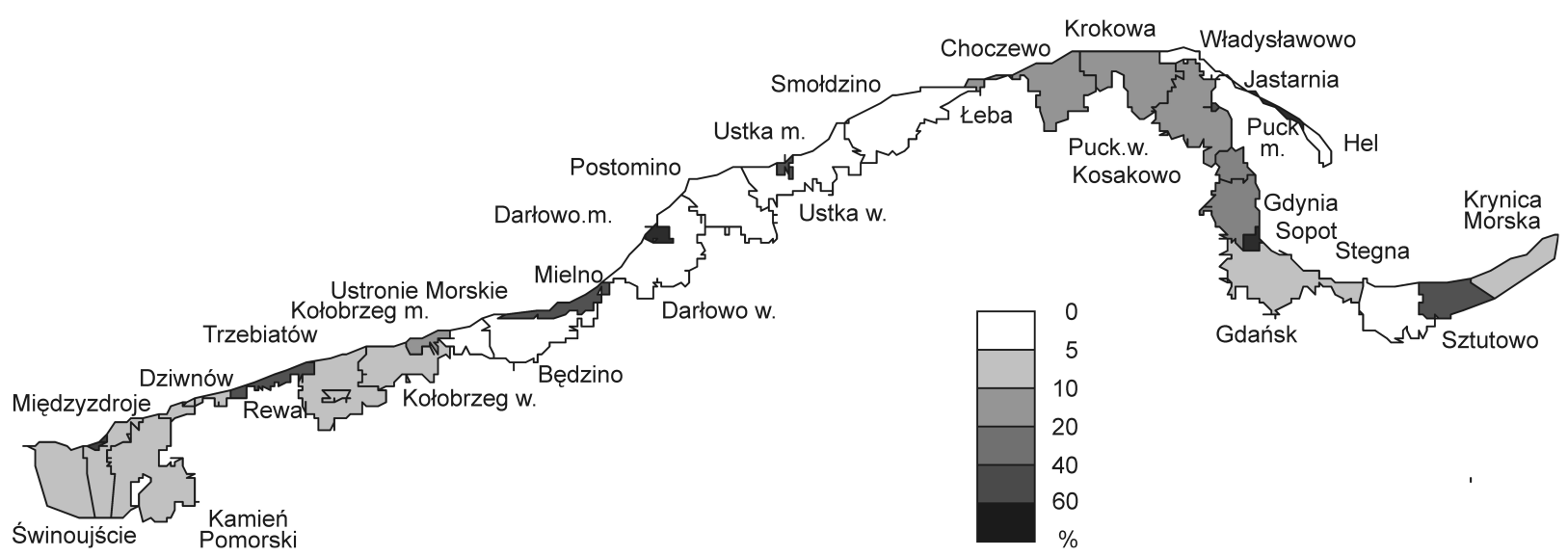

Rys. 4. Udział procentowy dofinansowania na projekty związane z turystyką w kwocie dofinansowania ogółem projektów realizowanych w gminach nadmorskich Pobrzeża Bałtyku

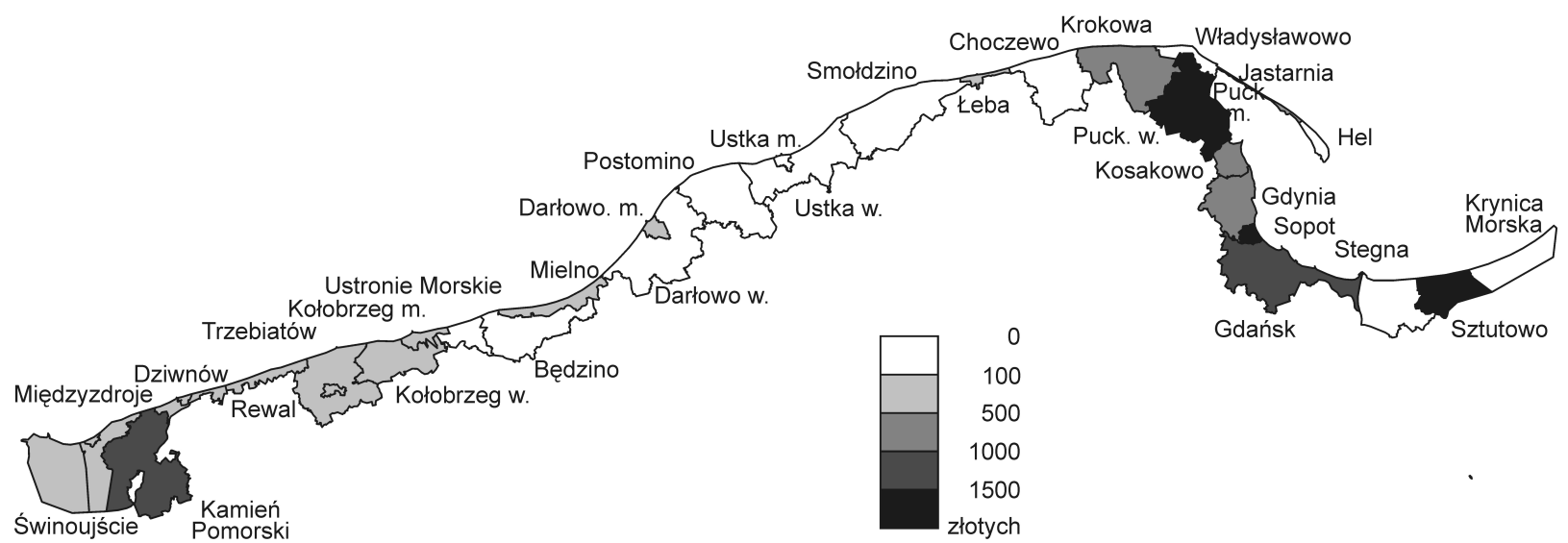

Rys. 5. Średnia kwota dofinansowania projektów związanych z turystyką realizowanych $\mathrm{w}$ gminach nadmorskich Pobrzeża Bałtyku przypadająca na jednego turystę odwiedzającego odpowiednie gminy nadmorskie

wo oraz gmina wiejska Ustka, a najwyższe otrzymały: gmina Gdańsk - 299629999 zł (49,4\% ogółu dofinansowania europejskiego priorytetów związanych z poprawą atrakcyjności turystycznej oraz $\mathrm{z}$ rozwojem zagospodarowania turystycznego $w$ gminach nadmorskich Pobrzeża Bałtyku) i Sopot - 107633909 zł $(17,7 \%)$. Wysoki poziom dofinansowania europejskiego charakteryzowały priorytety wspomagające turystykę w gminach: Gdynia, Jastarnia, Rewal, Świnoujście, Międzyzdroje i Darłowo oraz w gminie miejskiej Kołobrzeg.

Aby móc ocenić rzeczywistą siłę absorpcji funduszy europejskich priorytetów mających wpłynąć na poprawę atrakcyjności turystycznej oraz rozwój zagospodarowania turystycznego, określono udział procentowy dofinansowania projektów związanych $\mathrm{z}$ turystyką $\mathrm{w}$ skali dofinansowania ogółem oraz obliczenia średniej kwoty środków z priorytetów dotyczących poprawy atrakcyjności turystycznej i rozwoju zagospodarowania turystycznego przypadającej na jednego turystę odwiedzającego gminę. Uzyskane wy- niki wskazują, że najwyższy odsetek dofinansowania europejskiego projektów związanych z rozwojem turystyki charakteryzował gminy Międzyzdroje i Jastarnia oraz gminę miejską Darłowo (rys. 4). W gminach tych udział projektów dotyczących turystyki w skali dofinansowania europejskiego ogółem wynosił ponad $40,0 \%$. Wysoki poziom absorpcji funduszy europejskich był także w gminie Rewal $(38,2 \%)$ i gminie miejskiej Puck (35,3\%); w gminach: Ustronie Morskie, Postomino, Choczewo, Smołdzino, Hel i Będzino nie odnotowano dofinansowania projektów związanych $\mathrm{z}$ turystyką. Ponadto niewielki udział środków europejskich stwierdzono w gminach: Władysławowo, Stegna, Kosakowo, Świnoujście i w gminie wiejskiej Ustka.

Najwyższe kwoty na projekty wspomagające turystykę $\mathrm{w}$ przeliczeniu na jednego turystę odwiedzającego gminę uzyskano w gminie wiejskiej Puck (2687 zł), w gminach: Sztutowo (1845 zf), Sopot (ok. 1699 zf), miejskiej Puck (1550 zł), a także Kamień Pomorski, Gdańsk, Krokowa i Kosakowo (rys. 5). Nie przyznano 
środków z funduszy europejskich na projekty związane $\mathrm{z}$ poprawą atrakcyjności turystycznej oraz rozwojem zagospodarowania w gminach: Ustronie Morskie, Będzino, Darłowo - gmina wiejska, Postomino, Smołdzino, Hel oraz Choczewo. Niskie finansowanie dotyczyło gmin: Władysławowo, Ustka - gminy miejska i wiejska, Krynica Morska i Stegna. Warto jednocześnie dodać, że poziom przydzielanych środków na tego rodzaju projekty był silnie skorelowany $\mathrm{z}$ intensywnością ruchu turystycznego w gminach. Współczynnik korelacji Pearsona Wk osiągnął wartość 0,82 . Wyższe kwoty dofinansowania uzyskały gminy o wyższej frekwencji turystów. Dowodzi to wysokiej aktywności samorządów w staraniach o dalszy rozwój turystyki i poprawę atrakcyjności turystycznej oraz zagospodarowania turystycznego.

Dofinansowanie projektów dotyczących poprawy atrakcyjności turystycznej oraz rozwoju zagospodarowania turystycznego było objęte priorytetami: "Ochrona i waloryzacja dziedzictwa przyrodniczego" (56.), "Inne wsparcie na rzecz wzmocnienia usług turystycznych” (57.), "Ochrona i zachowanie dziedzictwa kulturowego" (58.), „Rozwój infrastruktury kulturalnej” (59.) oraz ,Zintegrowane programy rewaloryzacji obszarów miejskich i wiejskich" (61).

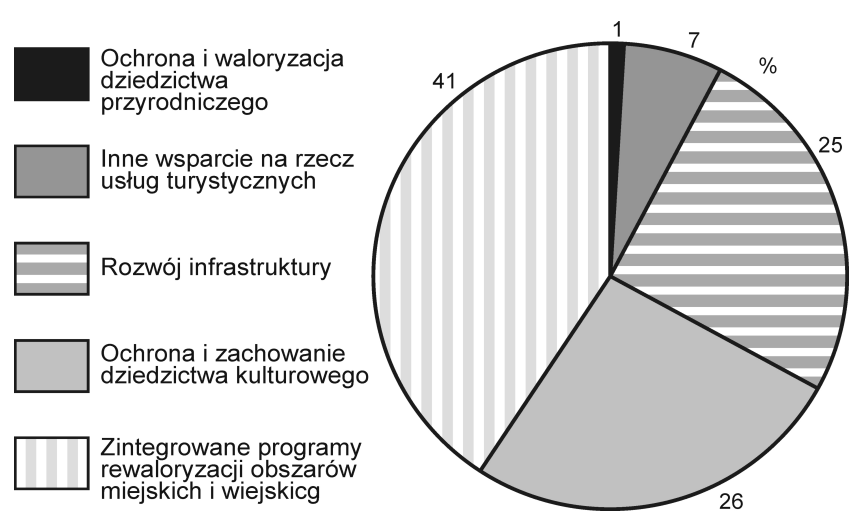

Rys. 6. Struktura wydatkowania środków finansowych z funduszy europejskich według priorytetów związanych z turystyką w gminach nadmorskich Pobrzeża Bałtyku

Analiza struktury dofinansowania projektów związanych z poprawą atrakcyjności turystycznej i rozwojem zagospodarowania turystycznego gmin nadmorskich Pobrzeża Bałtyku wskazuje, że największy udział w dofinansowaniu projektów związanych z turystyką miały priorytety: "Zintegrowane programy rewaloryzacji obszarów miejskich i wiejskich" (61.) - 41\% ogółu środków z dofinansowania, oraz „Ochrona dziedzictwa kulturowego" (58.) i "Rozwój infrastruktury kulturalnej" (59.) - por. rys. 6. Znacznie mniej projektów i mniejsze kwoty przeznaczono na realizację priorytetów: „Ochrona dziedzictwa przyrodni- czego" (56.) oraz "Inne wsparcie na rzecz wzmocnienia usług turystycznych" (57.).

Niskie dofinansowanie gmin nadmorskich funduszami z priorytetu: "Ochrona dziedzictwa przyrodniczego" może by efektem dominacji na obszarze nadmorskim typowej turystyki wypoczynkowej, przy mniejszym znaczeniu turystyki krajoznawczej oraz przyrodniczej. Niewielki udział środków z priorytetu „Inne wsparcie na rzecz wzmocnienia usług turystycznych" może wynikać z faktu, że większość inwestycji w sektorze usług turystycznych w strefie nadmorskiej to inwestycje prywatne, realizowane bez dofinansowania $z$ funduszy europejskich.

\section{WNIOSKI}

Analiza wykorzystania dofinansowania z funduszy europejskich w gminach nadmorskich Pobrzeża Bałtyku prowadzi do kilku wniosków.

1. Dofinansowanie projektów realizowanych z udziałem środków z funduszy europejskich jest najwyższe w największych gminach miejskich wybrzeża: aglomeracji trójmiejskiej, w Świnoujściu i Kołobrzegu.

2. Wykorzystanie funduszy europejskich na projekty dotyczące poprawy atrakcyjności turystycznej i rozwoju zagospodarowania turystycznego w gminach nadmorskich Pobrzeża Bałtyku jest silnie zróżnicowane. Obok dużych gmin, takich jak: Gdańsk, Gdynia czy Świnoujście, gdzie turystyka nie odgrywa dominującej roli, gminami o największym dofinansowaniu projektów związanych z rozwojem turystyki są: Rewal, Jastarnia, Międzyzdroje oraz Darłowo.

3. W wykorzystaniu dofinansowania funduszy europejskich na projekty dotyczące poprawy atrakcyjności turystycznej i zagospodarowania turystycznego zaznacza się przewaga gmin aglomeracji trójmiejskiej, a także zachodniej części Pobrzeża Szczecińskiego i obszaru wschodniej części Pobrzeża Szczecińskiego oraz zachodniej części Pobrzeża Koszalińskiego. Najniższym poziomem dofinansowania projektów związanych z turystyką charakteryzują się gminy wschodniej części Pobrzeża Koszalińskiego oraz zachodniej i wschodniej części Pobrzeża Gdańskiego.

4. Istnieje duża korelacja między poziomem wykorzystania środków finansowych $\mathrm{z}$ funduszy europejskich i intensywnością ruchu turystycznego. Gminy o wysokiej frekwencji turystycznej charakteryzują wysokie wskaźniki absorpcji środków z funduszy europejskich. 


\section{BIBLIOGRAFIA}

BUTOWSKI L., 2002, Finansowanie rozwoju turystyki ze środków Uni Europejskiej. Poradnik dla samorzadów terytorialnych i przedsiębiorców turystycznych, Polska Agencja Rozwoju Turystyki, Warszawa.

BUTOWSKI L., 2005, Finansowanie projektów turystycznych z funduszy strukturalnych Unii Europejskiej, Wyd. Akademickie Wyższej Szkoły Społeczno-Przyrodniczej w Lublinie, LublinWarszawa, 189 ss.

GWOSDZ K., MURZYN-KUPISZ M., 2010, Analiza wptywu inwestycji $w$ infrastrukture kultury $i$ turystyki dofinansowanych $z$ funduszy strukturalnych na rozwój społeczno-gospodarczy poszczególnych gmin/powiatów województwa śląskiego, Katowice.

KOŁODZIEJCZYK D., 2009, Fundusze unijne w budżecie samorządu terytorialnego, [w:] Problemy ekonomii, polityki ekonomicznej i finansów publicznych, J. Sokołowski (red.), Prace Naukowe Uniwersytetu Ekonomicznego we Wrocławiu, Wrocław, s. 111-117.

KOWALCZYK A., 2000, Geografia turyzmu, PWN, Warszawa, 287 ss. KUREK W., 2007, Turystyka, PWN, Warszawa, 541 ss.

MEYER B., 2006, Zmiany w wielkości i strukturze bazy noclegowej w gminie Rewal w latach 1988-2002, Zeszyty Naukowe Uniwersytetu Szczecińskiego, 439, „Ekonomiczne Problemy Turystyki", 6, s. 173-191.
MIEDZIŃSKI M., 2011, Kotobrzeg jako centrum turystyki uzdrowiskowo-wypoczynkowej po 20 latach przemian ustrojowych, [w:] Turystyka polska w latach 1989-2009, B. Włodarczyk, B. Krakowiak, J. Latosińska (red.), „Warsztaty z Geografii Turyzmu", Wyd. Uniwersytetu Łódzkiego, Łódź, s. 115-126.

PARZYCH K., 2012, Rola funduszy europejskich w podnoszeniu atrakcyjności i rozwoju zagospodarowania turystycznego gmin nadmorskich województwa pomorskiego, „Ekonomiczne Problemy Turystyki", 4, s. 267-281.

STAWICKI 2009, Fundusze europejskie w gminach, Rozwój lokalny, wykorzystanie środków europejskich, rekomendacje dla samorzadów, Warszawa, 184 ss.

SZWICHTENBERG A., 2006, Gospodarka turystyczna polskiego wybrzeża, Wyd. Politechniki Koszalińskiej, Koszalin, 368 ss.

ŻUBER P., 1999, Gospodarka turystyczna w zagranicznych programach pomocowych, [w:] Gospodarka turystyczna po reformie terytorialnej organizacji kraju. Aspekt regionalny, UKFiT-PARR, Kraków.

www.mrr.gov.pl; 15.12.2013.

Artykuł wpłyną: 21 kwietnia $2017 \mathrm{r}$ Zaakceptowano do druku: 29 czerwca $2017 \mathrm{r}$. 